A) Check for updates

Cite this: Food Funct., 2018, 9, 1465

\section{A natural food ingredient based on ergosterol: optimization of the extraction from Agaricus blazei, evaluation of bioactive properties and incorporation in yogurts $\uparrow$}

\author{
Rúbia C. G. Corrêa, (DD a,b,c Lillian Barros, (DD a Ângela Fernandes, (D) a Marina Sokovic, (DD d \\ Adelar Bracht, (D) ${ }^{b, c}$ Rosane M. Peralta (D) ${ }^{b}, \mathrm{c}$ and Isabel C. F. R. Ferreira (D) *a
}

\begin{abstract}
In recent years, mycosterols have emerged as potential functional ingredients for the development of sterol-enriched food products and dietary supplements. Agaricus blazei is a mushroom rich in bioactive compounds. For commercial purposes, their fruiting bodies must obey rigid morphological criteria. Those not conforming to these criteria are usually discarded, although this does not mean impairment of their content in bioactives. The aim of the present work was to propose the use of commercially discarded A. blazei fruiting bodies for obtaining an extract rich in ergosterol as a fortifier ingredient for yogurts. For extraction, the Soxhlet technology was used and the highest ergosterol yield (around 12\%) was achieved in the $5^{\text {th }}$ cycle, yielding $58.53 \pm 1.72 \mu \mathrm{g}$ of ergosterol per $100 \mathrm{~g}$ of mushroom (dry weight). The ergosterol rich extract presented notable antioxidant and antimicrobial properties, besides showing no hepatotoxicity. When added to the yogurts it significantly enhanced their antioxidant properties. Furthermore, it did not significantly alter the nutritional or the individual fatty acid profiles of the final dairy products. Thus, A. blazei fruiting bodies that do not conform to the commercial requirements of the market and are normally discarded could be exploited for obtaining a natural high added-value food additive, following the circular bioeconomy concept.
\end{abstract}

Received 20th December 2017, Accepted 6th February 2018

DOI: $10.1039 /$ c7fo02007d

rsc.li/food-function
Agaricus blazei Murrill (syn. Agaricus brasiliensis Wasser) is a Brazilian fungus widely known as the 'Sun Mushroom'. Currently, in several Oriental countries, A. blazei is consumed both as an edible mushroom, reputable as functional food, and for therapeutic ends, especially in the prevention and treatment of cancer. ${ }^{14,15}$ Among the high molecular weight compounds in A. blazei the most active ones include polysaccharides and protein-polysaccharide complexes containing beta-glucans, which possess proven anti-tumor, antiproliferative, anti-genotoxic and anti-mutagenic properties. ${ }^{14,15}$

However, A. blazei also holds diverse small bioactive molecules, as the compound named agarol, an ergosterol derivative with anti-cancer and anti-tumor potential. ${ }^{16}$

Although some studies have reported the optimization of ergosterol production using automated fermentative processes, ${ }^{17,18}$ a considerable volume of $A$. blazei fruiting bodies that do not fit into the commercial standard, and therefore are usually discarded by the mushroom producers, could be feasibly exploited for this purpose. ${ }^{1}$

Natural ingredients with antioxidant activity could be employed as substitutes for artificial additives, which might also display an important role in the prevention of various diseases related to oxidative/nitrosative stress, such as cancer, 
cardiovascular diseases and diabetes mellitus. ${ }^{19,20}$ Correspondingly, the antimicrobial properties of some natural active compounds could delay or inhibit the development of pathogenic and/or toxin-producing microorganisms in food, thus reducing the incidence of foodborne diseases provoked by food spoilage bacteria and fungi. ${ }^{21}$ Whereupon, the same bioactive extract could accumulate the functions of preservative and fortifying ingredients, thus improving both stability during the shelf life and the nutritional value of a foodstuff.

The successful application of A. blazei extracts as preservatives in yogurts was previously demonstrated by our research group, ${ }^{14}$ as well as the development of yogurts functionalized with both pure ergosterol and mycosterol extracts obtained from A. bisporus mushrooms. ${ }^{22}$ In these studies, maceration and ultrasound-assisted extraction (UAE), respectively, were adopted as extraction techniques. The aim of the present work was to prepare A. blazei extracts rich in ergosterol, obtained from their fruiting bodies via Soxhlet extraction, to be used as fortifier ingredients for yogurts. For this purpose, the antioxidant and antimicrobial activities of the extracts were evaluated, together with their hepatotoxicity. Furthermore, the developed dairy product was investigated in terms of nutritional composition, physico-chemical properties and antioxidant potential along its shelf life.

\section{Materials and methods}

\subsection{Standards and reagents}

HPLC-grade acetonitrile was obtained from Fisher Scientific (Lisbon, Portugal). Formic acid was purchased from Panreac AppliChem (Barcelona, Spain). 2,2-Diphenyl-1-picrylhydrazyl (DPPH) was obtained from Alfa Aesar (Ward Hill, MA, USA). Trolox (6-hydroxy-2,5,7,8-tetramethylchroman-2-carboxylic acid), and the sterol standards ergosterol (98\%) and cholecalciferol (98\%) were purchased from Sigma-Aldrich (St Louis, MO, USA), along with acetic acid, phosphate buffered saline (PBS), sulforhodamine $\mathrm{B}$ (SRB), trypan blue, trichloroacetic acid (TCA), tris(hydroxymethyl) aminomethane (TRIS), Dulbecco's Modified Eagle's Medium (DMEM), RPMI-1640 medium, fetal bovine serum (FBS), Hank's balanced salt solution (HBSS), L-glutamine, nonessential amino acid solution ( $2 \mathrm{mM}$ ), and penicillin/streptomycin solution. Also, the fatty acid methyl ester (FAME) reference standard mixture 37 (standard 47885-U) was purchased from Sigma (St Louis, MO, USA), as well as other individual fatty acid isomers and sugar standards. Mueller-Hinton agar (MH) and malt agar (MA) were obtained from the Institute of Immunology and Virology, Torlak (Belgrade, Serbia). All other chemicals and solvents were of analytical grade and purchased from common suppliers. Water was treated in a Milli-Q water purification system (TGI Pure Water Systems, Greenville, SC, USA).

\subsection{Development of the ingredient based on Agaricus blazei extracts}

2.2.1. Mushroom samples. Fruiting bodies (basidiocarps) of A. blazei were obtained from a local producer in Maringá,
Paraná, Brazil, in spring, 2016. The specimens were dried in a circulation oven at $40{ }^{\circ} \mathrm{C}$ and milled to a fine powder (40 mesh), then mixed to form homogenate samples. Finally, the samples were vacuum packed and stored at room temperature until analysis.

2.2.2. Optimization of the ergosterol extraction. The samples $(3.0 \mathrm{~g}$ ) were extracted with $100 \mathrm{~mL}$ of ethanol by refluxing in a Soxhlet apparatus. In order to optimize the extraction efficiency, the number of cycles in the Soxhlet system was taken into consideration, and up to eight cycles were assessed for ergosterol recovery. After the desired number of cycles, the solvent was removed under reduced pressure (rotary evaporator Büchi R-210, Flawil, Switzerland) for the obtainment of dried ethanolic extracts.

2.2.3. Ergosterol quantification. Ergosterol quantification was carried out according to Heleno et al. (2017) ${ }^{22}$ employing an HPLC equipment coupled with a UV detector. The equipment comprised an integrated system with a pump (Knauer, Smartline system 1000, Berlin, Germany), a degasser system (Smartline manager 5000), an auto-sampler (AS-2057 Jasco, Easton, MD) and a UV detector (Knauer Smartline 2500). Chromatographic separation was performed with an Inertsil 100A ODS-3 reversed-phase column $(4.6 \times 150 \mathrm{~mm}, 5 \mu \mathrm{m}$, BGB Analytik AG, Boeckten, Switzerland) operating at $35^{\circ} \mathrm{C}(7971 \mathrm{R}$ Grace oven). The mobile phase consisted of acetonitrile/methanol $(70: 30, \mathrm{v} / \mathrm{v})$ at a flow rate of $1 \mathrm{~mL} \mathrm{~min}^{-1}$, the injection volume was $20 \mu \mathrm{L}$ and the detection was achieved at $280 \mathrm{~nm}$. Ergosterol was quantified using a calibration curve obtained from a commercial standard using the internal standard method with cholecalciferol as the internal standard. Clarity 2.4 Software (DataApex) was employed for data analysis.

2.2.4. Evaluation of the antioxidant properties. To obtain the stock solutions of $5 \mathrm{mg} \mathrm{mL} \mathrm{m}^{-1}$, the dried extract was re-dissolved in ethanol. The mentioned stock solution was successively diluted until the determination of $\mathrm{EC}_{50}$ values (sample concentration providing a value of $50 \%$ in the $\mathrm{DPPH}$, $\beta$-carotene bleaching and TBARS assays or 0.5 absorbance in the reducing power assay). DPPH radical-scavenging activity, reducing power, inhibition of $\beta$-carotene bleaching and inhibition of lipid peroxidation employing thiobarbituric acid reactive substances (TBARS) were assayed using previous optimized methods $^{21}$ and Trolox was used as a positive control in all the assays.

2.2.5. Evaluation of the antimicrobial properties. For antibacterial activity investigation, the following Gram-negative bacteria were used: Escherichia coli (ATCC 35210), Salmonella enteritides (ATCC), Salmonella typhimurium (ATCC 13311), Enterobacter cloacae (ATCC 35030) and the following Grampositive bacteria: Staphylococcus aureus (ATCC 6538), Bacillus cereus (clinical isolate), Micrococcus flavus (ATCC 10240), and Listeria monocytogenes (NCTC 7973). For the antifungal bioassays the following microfungi were tested: Aspergillus fumigatus (1022), Aspergillus ochraceus (ATCC 12066), Aspergillus versicolor (ATCC 11730), Aspergillus niger (ATCC 6275), Candida crusei (human isolate), Penicillium funiculosum (ATCC 36839) and Penicillium verrucosum var. cyclopium (food isolate). In 
order to investigate the antimicrobial potential of the A. blazei ethanolic extract, a modified microdilution technique was applied. ${ }^{23}$ Minimum inhibitory concentration (MIC) determinations were performed by a serial dilution technique using 96-well microtiter plates. Both minimum bactericidal concentrations (MBCs) and minimum fungicidal concentrations (MFCs) were determined by serial subcultivation of a $2 \mathrm{~mL}$ sample into microtiter plates containing $100 \mathrm{~mL}$ of broth per well and further incubation for $48 \mathrm{~h}$ at $37^{\circ} \mathrm{C}$ or $72 \mathrm{~h}$ at $28{ }^{\circ} \mathrm{C}$, as previously described by Stojković et al. (2017). ${ }^{24}$ The lowest concentrations with no visible growth were designated as MBC/MFC, corresponding to $99.5 \%$ killing of the original inoculum. In the antibacterial assays, streptomycin (ICN-Galenika, Belgrade, Serbia) and ampicillin (Panfarma, Belgrade, Serbia) were used as positive controls, while in antifungal tests the commercial fungicides bifonazole (Srbolek, Belgrade, Serbia) and ketoconazole (Zorkapharma, Sabac, Serbia) were used (at the concentration of $1 \mathrm{mg} \mathrm{mL} \mathrm{m}^{-1}$ in sterile physiological saline); $30 \%$ EtOH was used as a negative control.

2.2.6. Evaluation of the hepatotoxicity. The A. blazei ethanolic extract was dissolved in water at $4 \mathrm{mg} \mathrm{mL}^{-1}$ and then subjected to further dilutions. A cell culture (assigned as PLP2) was obtained from a freshly harvested porcine liver acquired from a local slaughterhouse, following a procedure described by Abreu et al. $(2011)^{25}$ and the sulforhodamine B assay was performed to evaluate the extract's hepatotoxic potential. Ellipticine was used as a positive control, with results expressed in $\mathrm{GI}_{50}$ values (concentration that inhibited $50 \%$ of the net cell growth).

\subsection{Fortification of yogurts with the $A$. blazei ergosterol rich extract}

2.3.1. Incorporation procedure. Two groups of samples were prepared (yogurts with $50 \mathrm{~g}$ each): control samples (commercial yogurts without additives) and samples added with the A. blazei ergosterol rich extract. For each portion of $50 \mathrm{~g}$ of yogurt, $737 \mathrm{mg}$ of the ethanolic extract were incorporated, providing two times the highest $\mathrm{EC}_{50}$ value obtained for the antioxidant activity. Natural plain yogurts were purchased from a local market in Bragança, Portugal, and used as control samples. All analyses were carried out immediately after preparation and after seven days of storage at $4{ }^{\circ} \mathrm{C}$.

2.3.2. Nutritional analyses. The proximate composition of the samples (moisture, protein, fat, ash and carbohydrates) was assessed using the AOAC $(2016)^{26}$ procedures. The crude protein content $(\mathrm{N} \times 6.38)$ of the samples was determined by the Kjeldahl method; the crude fat was estimated by extracting a known weight of powdered sample with petroleum ether, using a Soxhlet apparatus; the ash content was assessed by incineration at $600 \pm 15^{\circ} \mathrm{C}$ and total carbohydrates were calculated by difference. Total energy was calculated according to the following equation: Energy $(\mathrm{kcal})=4 \times(\mathrm{g}$ proteins + $\mathrm{g}$ carbohydrates $)+9 \times(\mathrm{g}$ lipids $)$. Free sugars were detected by HPLC coupled to a refraction index detector and the identification was performed by comparison with standards, and further quantified (g per $100 \mathrm{~g}$ of yogurt) by using an internal standard (melezitose). Fatty acids were assessed by GC coupled to a FID detector and the identification was performed by comparison with commercial standards. Results were expressed as the relative percentage of each fatty acid.

2.3.3. Physico-chemical analyses. Physico-chemical analyses were performed by measuring the color of the samples using a colorimeter (model CR-400, Konica Minolta Sensing Inc., Tokyo, Japan). With the illuminant $\mathrm{C}$ and diaphragm aperture of $8 \mathrm{~mm}$, the CIE $L / a / b /$ color space values were registered using a data software "Spectra Magic Nx" (version CM-S100 W 2.03.0006) (Caleja et al., 2016). ${ }^{20}$ The $\mathrm{pH}$ of the samples was directly assessed in the samples with a HI 99161 pH-meter (Hanna Instruments, Woonsocket, Rhode Island, USA).

2.3.4. Incorporation procedure. The samples were lyophilized and further extracted with ethanol at room temperature for $1 \mathrm{~h}$ under stirring, as previously described by Caleja et al. (2016). ${ }^{20}$ The obtained extracts were evaluated for the DPPH radical-scavenging activity and reducing power (following the procedures described above) at 515 and $690 \mathrm{~nm}$, respectively, using the ELX800 microplate reader (Bio-Tek Instruments, Inc., Winooski, Vermont, USA).

\subsection{Statistical analysis}

All results were expressed as mean values and standard deviations (SD), as an outcome of the three repetitions of the samples and concentrations that were used in all the assays. One-way analysis of variance (ANOVA) followed by Tukey's HSD test $(p=0.05)$ were applied to analyze the results of the extraction optimization. Moreover, to determine significant differences with $\alpha=0.05$ between less than three samples, a Student's $t$-test was applied for all the remaining results. Analyses were carried out using IBM SPSS Statistics for Windows, version 23.0. (IBM Corp., Armonk, New York, USA).

\section{Results and discussion}

\subsection{Ergosterol quantification in the optimized extracts}

The Soxhlet extraction methodology has been widely applied for the recovery of valuable bioactive molecules (compounds of interest) from diverse natural sources, including mushrooms. ${ }^{27}$ It is commonly used as a model for comparisons when emerging extraction technologies are investigated. ${ }^{28}$ There are a number of papers communicating the obtainment and quantification of ergosterol fractions from $A$. bisporus via either conventional techniques such as maceration ${ }^{29}$ and soxhlet, ${ }^{28,30}$ and emerging extraction methods such as ultrasound assisted extraction $(\mathrm{UAE})^{28}$ and microwave-assisted extraction (MAE) together with the response surface methodology (RSM). ${ }^{31}$ However, except for the reports of Gao \& Gu (2007), ${ }^{17}$ Shu \& Lin (2011) ${ }^{18}$ and Mazzutti et al. (2012), ${ }^{32}$ papers describing the optimized production/ extraction of bioactive molecules from A. blazei remain scarce. To the best of our knowledge, there are no references in the literature reporting the optimized extraction of ergosterol from A. blazei by means of the Soxhlet technology. 
Table 1 presents the yields of ergosterol extraction from A. blazei fruiting bodies in the optimization study, which comprised eight Soxhlet cycles, along with the correspondent ergosterol quantification. The highest ergosterol yield (around $12 \%$ ) was achieved in the $5^{\text {th }}$ Soxhlet cycle, yielding $58.53 \pm$ $1.72 \mu \mathrm{g}$ of ergosterol per $100 \mathrm{~g}$ of mushroom bio-residues (dry weight). The herein obtained ergosterol yield is lower than the values reported by Heleno et al. $(2016)^{28}$ and Heleno et al. $(2016)^{31}$ for ergosterol extraction from A. bisporus using emerging extraction technologies. Although a previous work by our group (Stojković et al., 2014) ${ }^{14}$ has already confirmed that the A. bisporus mushroom has a higher ergosterol content than A. blazei, it is interesting to note that the latter species, however, represents an absolutely interesting and viable source for obtaining fractions of ergosterol. In particular, we consider the surplus of fruiting bodies that are discarded during the A. blazei production chain, because they do not conform to the high commercial standards (bio-residues that are usually lost).

\subsection{Bioactive properties of the A. blazei extract rich in ergosterol}

The investigation of the A. blazei bioactivities was performed only for the sample referring to the optimum ergosterol extraction point, that is, the extract obtained with five cycles of extraction with a yield of $12.19 \%$ (Table 1 ).

It is already established that extracts obtained from A. blazei exert their antioxidant activity in a dose-dependent manner, with a direct correlation between the antioxidant activity and the reducing power. ${ }^{15}$ Depending on the extraction solution (such as hot or cold water, alcoholic and hydroalcoholic solutions or enzyme solutions), as well as the extraction technique adopted, distinct yields and levels of free radical scavengers can be achieved. ${ }^{33}$ Both methanol and ethanol have been successfully employed in the extraction of non-polysaccharidic antioxidants from $A$. blazei. ${ }^{34}$

The herein studied A. blazei extract rich in ergosterol displayed a considerable antioxidant activity in all four bioassays (Table 2), with the lowest $\mathrm{EC}_{50}$ values for the TBARS inhibition $\left(0.09 \pm 0.002 \mathrm{mg} \mathrm{mL}^{-1}\right)$ and $\beta$-carotene/linoleate $(2.12 \pm$ $0.06 \mathrm{mg} \mathrm{mL} \mathrm{m}^{-1}$ ) assays. Carneiro et al. $(2013)^{35}$ found $\mathrm{EC}_{50}$

Table 1 Optimization study of the ergosterol extraction

\begin{tabular}{llll}
\hline $\begin{array}{l}\text { Number of } \\
\text { Soxhlet cycles }\end{array}$ & $\begin{array}{l}\text { Extraction } \\
\text { yield }\end{array}$ & $\begin{array}{l}\text { Ergosterol } \\
\left(\mu \mathrm{g} \mathrm{g}^{-1} \text { of extract }\right)\end{array}$ & $\begin{array}{l}\text { Ergosterol } \\
(\mu \mathrm{g} \text { per 100g dw })\end{array}$ \\
\hline Cycle 1 & $0.67 \pm 0.01^{\mathrm{g}}$ & $0.90 \pm 0.01^{\mathrm{e}}$ & $0.60 \pm 0.01^{\mathrm{h}}$ \\
Cycle 2 & $1.90 \pm 0.07^{\mathrm{f}}$ & $4.50 \pm 0.02^{\mathrm{b}}$ & $8.55 \pm 0.03^{\mathrm{g}}$ \\
Cycle 3 & $4.45 \pm 0.13^{\mathrm{e}}$ & $4.75 \pm 0.07^{\mathrm{a}}$ & $21.15 \pm 0.31^{\mathrm{f}}$ \\
Cycle 4 & $6.78 \pm 0.02^{\mathrm{d}}$ & $4.45 \pm 0.07^{\mathrm{b}}$ & $30.17 \pm 0.48^{\mathrm{e}}$ \\
Cycle 5 & $12.19 \pm 0.01^{\mathrm{a}}$ & $4.80 \pm 0.14^{\mathrm{a}}$ & $58.53 \pm 1.72^{\mathrm{a}}$ \\
Cycle 6 & $11.84 \pm 0.32^{\mathrm{b}}$ & $3.75 \pm 0.07^{\mathrm{c}}$ & $44.39 \pm 0.84^{\mathrm{b}}$ \\
Cycle 7 & $10.79 \pm 0.04^{\mathrm{c}}$ & $3.80 \pm 0.02^{\mathrm{c}}$ & $40.99 \pm 0.01^{\mathrm{c}}$ \\
Cycle 8 & $10.76 \pm 0.11^{\mathrm{c}}$ & $3.40 \pm 0.01^{\mathrm{d}}$ & $30.58 \pm 0.02^{\mathrm{d}}$
\end{tabular}

The results are presented as mean \pm SD. dw: dry weight. In each column different letters mean significant statistical differences $(p<$ 0.05).
Table 2 Antioxidant activity and hepatotoxicity of the Agaricus blazei ethanolic extract (mean \pm SD)

Agaricus blazei

ethanolic extract

Antioxidant activity $\mathrm{EC}_{50}$ values $\left(\mathrm{mg} \mathrm{mL}^{-1}\right)^{\mathrm{A}}$

DPPH scavenging activity

$7.37 \pm 0.23$

Reducing power

$\beta$-Carotene bleaching inhibition

TBARS inhibition

$2.62 \pm 0.05$

$2.12 \pm 0.06$

$0.09 \pm 0.002$

Hepatotoxicity $\mathrm{GI}_{50}$ values $\left.(\mu \mathrm{g} \mathrm{mL})^{-1}\right)^{\mathrm{B}}$

PLP2

$>400$

$\mathrm{EC}_{50}$ values correspond to the sample concentration achieving $50 \%$ of antioxidant activity or 0.5 of absorbance in the reducing power assay. $\mathrm{GI}_{50}$ values correspond to the sample concentration achieving $50 \%$ of growth inhibition in liver primary culture PLP2. A - Trolox $\mathrm{EC}_{50}$ values: $42 \mu \mathrm{g} \mathrm{mL} \mathrm{m}^{-1}$ (DDPH), $41 \mu \mathrm{g} \mathrm{mL} \mathrm{L}^{-1}$ (reducing power), $18 \mu \mathrm{g} \mathrm{mL}^{-1}$ ( $\beta$-carotene bleaching inhibition), $23 \mu \mathrm{g} \mathrm{mL}^{-1}$ (TBARS inhibition); $\mathrm{B}$ ellipticine $\mathrm{GI}_{50}$ value: $2.29 \mu \mathrm{g} \mathrm{mL}^{-1}$ (PLP2).

values similar to ours $\left(0.30 \pm 0.03 \mathrm{mg} \mathrm{mL}^{-1}\right.$ for the TBARS assay, $2.23 \pm 0.12 \mathrm{mg} \mathrm{mL}{ }^{-1}$ for the reducing power assay and $6.77 \pm 0.43 \mathrm{mg} \mathrm{mL}^{-1}$ for the DPPH assay), when investigating the antioxidant capacity of a methanolic extract of A. blazei obtained from a nutraceutical powdered mushroom supplement using maceration. Stojković et al. $(2014)^{14}$ also found similar results when performing the reducing powder and the $\beta$-carotene/linoleate assays $\left(\mathrm{EC}_{50}\right.$ values of $2.01 \pm 0.04 \mathrm{mg} \mathrm{mL}$ and $2.85 \pm 0.34 \mathrm{mg} \mathrm{mL}^{-1}$, respectively) for an A. blazei ethanolic extract obtained via the maceration procedure. However, the same authors found better results of antioxidant capacity in the DPPH assay $\left(4.17 \pm 0.09 \mathrm{mg} \mathrm{mL} \mathrm{m}^{-1}\right)$, in addition to a considerably lower antioxidant activity in the TBARS inhibition method $\left(1.80 \pm 0.26 \mathrm{mg} \mathrm{mL}^{-1}\right)$. Mazzutti et al. (2012), ${ }^{32}$ in their study over the use of supercritical fluid and other conventional technologies for the production of $A$. blazei bioactive extracts, found a much lower antioxidant capacity when performing the $\mathrm{DPPH}$ assay $\left(\mathrm{EC}_{50}=1.05 \mathrm{mg} \mathrm{mL}^{-1}\right)$ for an ethanolic extract obtained by Soxhlet extraction.

Without a previous positive determination that their utilization is safe, official regulatory bodies cannot permit the utilization of food additives by the food industry. With this view, the performed toxicity assessment is of great importance, since mammalian hepatocytes still represent an obligatory step in the evaluation of toxic compounds that lead to the production of various metabolites, which are the ultimate cause of toxicity (Abreu et al., 2011). ${ }^{25}$ In our experiment, we employed porcine liver as an in vitro cytotoxicity model because of its similarity, in terms of cellular and physiological functioning, with the human liver. Our A. blazei extract rich in ergosterol did not show hepatotoxicity tested in PLP2 cells, up to the maximum concentration of $400 \mu \mathrm{g} \mathrm{mL} \mathrm{m}^{-1}$ (Table 2), which not only corroborates the results reported by Stojković et al. $(2014)^{14}$ and Heleno et al. (2017), ${ }^{22}$ but also endorses its safe application as a food additive.

We assessed the antimicrobial potential of the extract rich in ergosterol against foodborne pathogens and spoilage agents 
that can be found in dairy products, including some mycotoxin producing fungi. The A. blazei extract's minimum inhibitory concentrations (MICs), minimum bactericidal concentrations (MBCs) and minimum fungicidal concentrations (MFCs) for eight Gram-negative and Gram-positive bacteria and for seven fungi are presented in Table 3.

The MIC values reveal that the A. blazei ergosterol rich extract displayed excellent bacteriostatic effects against all tested bacteria, and also presented considerable bactericidal potential against these microorganisms, being especially potent against Enterobacter cloacae and Salmonella enteritidis (MBC values of $0.05 \mathrm{mg} \mathrm{mL} \mathrm{mL}^{-1}$ ). Stojković et al. $(2014)^{14}$ observed significantly lower bacteriostatic effects against Micrococcus flavus (MIC of $1.7 \mathrm{mg} \mathrm{mL}^{-1}$ ), Listeria monocytogenes and E. cloacae (MICs of $2.35 \mathrm{mg} \mathrm{mL}{ }^{-1}$ ), S. interitides and S. typhimurium (MICs of $3.6 \mathrm{mg} \mathrm{mL}^{-1}$ ) for an A. blazei ethanolic extract obtained by maceration. However, their extract was more effective against Staphylococcus aureus and Bacillus cereus (MICs of $0.03 \mathrm{mg} \mathrm{mL}^{-1}$ ). Mazzutti et al. (2012) ${ }^{32}$ also reported lower antibacterial activities against B. cereus and $S$. aureus for the ethanolic extracts of $A$. blazei obtained via Soxhlet and maceration (all MIC values were $>20 \mathrm{mg} \mathrm{mL}^{-1}$ ).

Regarding the antifungal potential, our $A$. blazei extract rich in ergosterol displayed good inhibition of all tested fungi, however being more effective against Aspergillus versicolor (MIC of $0.20 \mathrm{mg} \mathrm{mL}^{-1}$ ). Stojković et al. (2014) ${ }^{14}$ obtained less expressive results for the inhibition of Aspergillus fumigatus (MIC of $2.35 \mathrm{mg} \mathrm{mL}^{-1}$ ), A. ochraceus and Penicillium funiculosum (MICs of $1.125 \mathrm{mg} \mathrm{mL}^{-1}$ ), and A. niger and P. verrucosum var. cyclopium (MICs of. $2.35 \mathrm{mg} \mathrm{mL} \mathrm{mL}^{-1}$ ). However, their A. blazei ethanolic extract was more active against $A$. versicolor (MIC of $0.15 \mathrm{mg} \mathrm{mL}^{-1}$ ) than our extract.

According to their MIC values, natural products can be considered strong inhibitors (MIC below $0.5 \mathrm{mg} \mathrm{mL}^{-1}$ ), moderate inhibitors (MIC between 0.6 and $1.5 \mathrm{mg} \mathrm{mL}^{-1}$ ), and weak inhibitors (MIC above $1.6 \mathrm{mg} \mathrm{mL}^{-1}$ ). ${ }^{32,36}$ Thus, based on these parameters, the herein investigated A. blazei ergosterol rich extract can be classified as a strong inhibitor against all bacteria assessed. Moreover, the A. blazei extract was more effective than the antibiotic ampicillin at inhibiting all the tested bacteria, while it was more potent than streptomycin against M. flavus, E. cloacae, S. enteritidis and S. typhimurium. Furthermore, except for the case of A. versicolor (MIC $<0.5 \mathrm{mg}$ $\mathrm{mL}^{-1}$ ), our A. blazei extract was a moderate inhibitor against all other fungi assessed. However, the extract was more efficient than the fungicide ketaconazole at inhibiting the growth of A. ochraceus. The A. blazei extract's promising antimicrobial potential offers the perspective of being explored in food applications, not only to improve food products' nutritional profiles but also to enhance their microbiological stability and consequently extend their shelf-life.

\subsection{Fortification of yogurts with the A. blazei ergosterol rich extract}

With the aim of confirming the viability of using A. blazei to obtain ergosterol rich extracts to be applied as natural func-

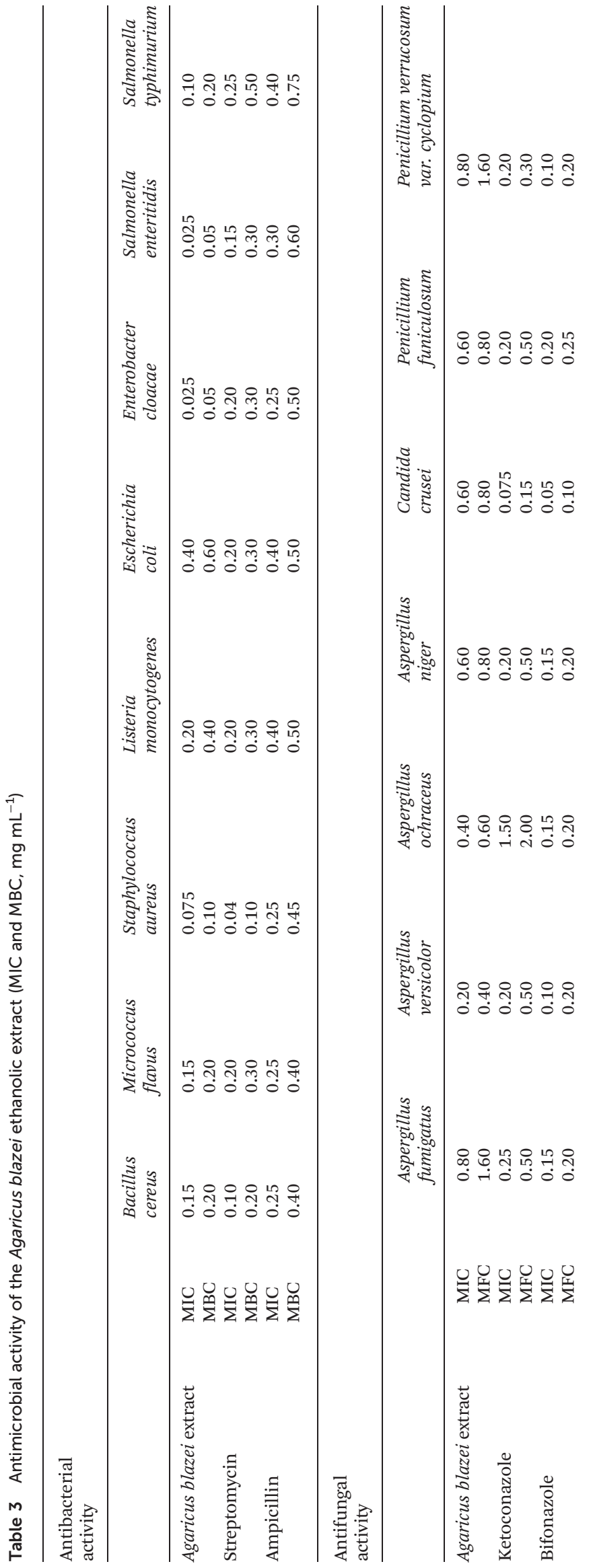


tional additives, i.e. fortifier ingredients for food products, a detailed analysis of the developed dairy product was carried out, including the evaluation of the nutritional profile, soluble sugars, fatty acids, color, $\mathrm{pH}$ and antioxidant activity. Both yogurt samples, namely control and fortified, were analyzed after two storage periods (immediately after incorporation and after seven days of storage at $4{ }^{\circ} \mathrm{C}$ ). The results are presented in Tables 4-6.

Table 4 shows the nutritional profile, energy values and physico-chemical parameters for the assessed yogurt samples. As expected for yogurts, moisture was the parameter with the highest value; in the same way, total carbohydrates were the most abundant macronutrient, followed by proteins. The moisture values found in our samples (average of $84.79 \mathrm{~g}$ per $100 \mathrm{~g})$ were close to the ones reported by Caleja et al. $(2016)^{20}$ (average $87.47 \mathrm{~g}$ per $100 \mathrm{~g}$ ) for homemade yogurts added with natural antioxidant preservatives, and to the values found by Heleno et al. $(2017)^{22}$ (average $81.00 \mathrm{~g}$ per $100 \mathrm{~g}$ ) when analyzing commercial beverage yogurts added with the A. bisporus ethanolic extract and pure ergosterol. Total carbohydrate contents found for both the control and fortified samples (average of $5.36 \mathrm{~g}$ per $100 \mathrm{~g}$ ) were similar to the value reported by Caleja et al. $(2016)^{20}$ (average of $5.55 \mathrm{~g}$ per $100 \mathrm{~g}$ ), however much lower than the values found by Heleno et al. $(2017)^{22}$ (average of $12 \mathrm{~g}$ per $100 \mathrm{~g}$ ). Regarding protein and fat contents (average of $5.62 \mathrm{~g}$ per $100 \mathrm{~g}$ and $3.24 \mathrm{~g}$ per $100 \mathrm{~g}$, respectively), our samples presented higher values than the ones reported by both Caleja et al. (2016) ${ }^{20}$ and Heleno et al. (2017), ${ }^{22}$ who found values ranging from 3.77 to $4.20 \mathrm{~g}$ per $100 \mathrm{~g}$ for the protein content and from $1.46 \mathrm{~g}$ to $2.30 \mathrm{~g}$ per $100 \mathrm{~g}$ for the fat content. These macronutrients' discrepancies could be explained by the use of distinct yogurt brands and/or homemade yogurt. Nevertheless, the ash content of our samples was really close to the average value found by Caleja et al. (2016). ${ }^{20}$
Two free sugars were identified and quantified in our samples, namely galactose (average of $1.01 \mathrm{~g}$ per $100 \mathrm{~g}$ ) and lactose (4.17 g per $100 \mathrm{~g}$ ) (Table 4). Heleno et al. $(2017)^{22}$ reported similar contents $(1.1 \mathrm{~g}$ per $100 \mathrm{~g}$ of galactose and $3.8 \mathrm{~g}$ per $100 \mathrm{~g}$ of lactose) for a yogurt fortified with A. bisporus extracts rich in ergosterol. The contents of total free sugars in our samples remained practically unchanged during the storage period. Overall, the incorporation of the A. blazei extract rich in ergosterol did not significantly impact the nutritional profile of the yogurts, and considering that the samples were stored at an adequate temperature, few alterations were expected for the assessed shelf-life period (7 days).

Two physico-chemical parameters, color and $\mathrm{pH}$, were determined in the yogurts (Table 4). Color was measured via a CIELAB color scale, assessing the $L^{*}(100=$ white; $0=$ black $)$, $a^{*}(-$, red; +, green $)$ and $b^{*}(-$, yellow; +, blue $)$ parameters. The fortified samples were redder, yellower and darker than the control samples, being that over the storage time the $L^{*}$ parameter decreased while the $a^{*}$ and $b^{*}$ parameters increased. Similar results were reported by Vital et al. $(2015)^{37}$ when investigating the incorporation of a bioactive aqueous extract of Pleurotus ostreatus into low fat yogurts. The incorporation actually changed the color of the yogurt to the naked eye, as can be observed in the ESI. $\dagger$ This colorant property of the A. blazei extract could be rather interesting in the case of its incorporation into flavored yogurts, for example yogurts added with plum, nuts and oat. Moreover, the A. blazei extract incorporation promoted a slight acidification of the yogurt samples (with a pH decrease of $2.32 \%$ ) (Table 4). Yet, the $\mathrm{pH}$ increased over the storage period studied in the same proportion, for both the control and fortified samples.

Twenty-four fatty acids (FA) were identified and quantified in the yogurt samples, and the results expressed in relative percentage are shown in Table 5. Among these, the most abun-

Table 4 Macronutrients, free sugar compositions ( $\mathrm{g}$ per $100 \mathrm{~g}$ ) and energy values (kcal per $100 \mathrm{~g}$ ) of the yogurts along the shelf life

\begin{tabular}{|c|c|c|c|c|c|c|c|c|c|}
\hline \multirow[t]{2}{*}{0 days } & Control & $85.25 \pm 0.17$ & $3.18 \pm 0.01$ & $5.61 \pm 0.01$ & $5.21 \pm 0.02$ & $0.76 \pm 0.01$ & $71.88 \pm 0.06$ & $0.99 \pm 0.01$ & $4.15 \pm 0.03$ \\
\hline & $p$-Student's t-test & 0.035 & 0.006 & 0.005 & 0.005 & 0.008 & 0.005 & 0.002 & 0.039 \\
\hline \multirow[t]{2}{*}{7 days } & Control & $84.75 \pm 0.11$ & $3.29 \pm 0.02$ & $5.73 \pm 0.01$ & $5.49 \pm 0.01$ & $0.75 \pm 0.01$ & $74.41 \pm 0.06$ & $1.03 \pm 0.01$ & $4.12 \pm 0.04$ \\
\hline & Fortified & $84.09 \pm 0.20$ & $3.23 \pm 0.05$ & $5.56 \pm 0.01$ & $5.35 \pm 0.04$ & $0.77 \pm 0.01$ & $72.65 \pm 0.31$ & $0.99 \pm 0.02$ & $4.18 \pm 0.01$ \\
\hline
\end{tabular}

Physico-chemical parameters

\begin{tabular}{|c|c|c|c|c|c|}
\hline Storage time & Sample & $L^{*}$ & $a^{*}$ & $b^{*}$ & $\mathrm{pH}$ \\
\hline & Fortified & $84.84 \pm 0.13$ & $0.45 \pm 0.03$ & $10.00 \pm 0.06$ & $4.21 \pm 0.15$ \\
\hline \multirow[t]{3}{*}{7 days } & Control & $90.37 \pm 0.20$ & $-2.51 \pm 0.01$ & $20.27 \pm 0.19$ & $4.45 \pm 0.20$ \\
\hline & Fortified & $83.20 \pm 0.25$ & $1.32 \pm 0.21$ & $19.70 \pm 0.17$ & $4.32 \pm 0.09$ \\
\hline & $p$-Student's $t$-test & $<0.001$ & $<0.001$ & $<0.001$ & 0.202 \\
\hline
\end{tabular}

In each column and within each storage time a Student's $t$-test was performed to determine the significant difference between two different samples, with $\alpha=0.05: p>0.001$ means a significant difference between the samples. 
Table 5 Fatty acid compositions of the yogurts, in relative percentage of each fatty acid, along the shelf life

\begin{tabular}{|c|c|c|c|c|c|c|}
\hline & \multicolumn{6}{|l|}{ Storage time } \\
\hline & \multicolumn{3}{|l|}{0 days } & \multicolumn{3}{|l|}{7 days } \\
\hline & Control & Fortified & $p$-Student's $t$-test & Control & Fortified & $p$-Student's $t$-test \\
\hline $\mathrm{C} 4: 0$ & $4.54 \pm 0.10$ & $4.32 \pm 0.05$ & 0.007 & $3.64 \pm 0.05$ & $5.35 \pm 0.09$ & $<0.001$ \\
\hline C6:0 & $3.71 \pm 0.18$ & $4.23 \pm 0.31$ & 0.022 & $3.55 \pm 0.19$ & $4.46 \pm 0.13$ & 0.001 \\
\hline C8:0 & $2.08 \pm 0.15$ & $2.44 \pm 0.08$ & 0.006 & $2.31 \pm 0.21$ & $2.53 \pm 0.12$ & 0.091 \\
\hline C10:0 & $3.86 \pm 0.30$ & $4.57 \pm 0.02$ & 0.004 & $4.49 \pm 0.29$ & $4.59 \pm 0.23$ & 0.547 \\
\hline C11:0 & $0.05 \pm 0.01$ & $0.06 \pm 0.00$ & 0.002 & $0.06 \pm 0.05$ & $0.06 \pm 0.01$ & 0.343 \\
\hline C12:0 & $3.68 \pm 0.18$ & $4.27 \pm 0.04$ & 0.001 & $4.14 \pm 0.17$ & $4.14 \pm 0.13$ & 0.983 \\
\hline C13:0 & $0.09 \pm 0.03$ & $0.10 \pm 0.01$ & 0.002 & $0.10 \pm 0.02$ & $0.10 \pm 0.02$ & 0.673 \\
\hline C14:0 & $10.64 \pm 0.09$ & $11.72 \pm 0.16$ & 0.001 & $11.14 \pm 0.24$ & $11.27 \pm 0.03$ & 0.244 \\
\hline C14:1 & $0.81 \pm 0.01$ & $0.89 \pm 0.01$ & 0.001 & $0.85 \pm 0.02$ & $0.88 \pm 0.05$ & 0.083 \\
\hline C15:0 & $1.29 \pm 0.04$ & $1.29 \pm 0.05$ & 0.019 & $1.34 \pm 0.01$ & $1.27 \pm 0.01$ & 0.001 \\
\hline C16:0 & $27.43 \pm 0.41$ & $27.89 \pm 0.43$ & 0.133 & $27.69 \pm 0.06$ & $27.24 \pm 0.27$ & 0.016 \\
\hline C16:1 & $1.22 \pm 0.03$ & $1.31 \pm 0.09$ & 0.06 & $1.28 \pm 0.02$ & $1.32 \pm 0.04$ & 0.062 \\
\hline C17:0 & $0.90 \pm 0.02$ & $0.85 \pm 0.02$ & 0.01 & $0.91 \pm 0.01$ & $0.84 \pm 0.01$ & $<0.001$ \\
\hline C18:0 & $9.61 \pm 0.01$ & $9.92 \pm 0.18$ & 0.013 & $9.35 \pm 0.26$ & $9.65 \pm 0.22$ & 0.096 \\
\hline C18:1n9 & $21.78 \pm 0.25$ & $21.83 \pm 0.53$ & 0.837 & $20.57 \pm 0.53$ & $22.06 \pm 0.21$ & 0.003 \\
\hline C18:2n6 & $5.03 \pm 0.34$ & $2.14 \pm 0.04$ & 0.001 & $5.50 \pm 0.15$ & $2.07 \pm 0.04$ & $<0.001$ \\
\hline C18:3n3 & $1.40 \pm 0.06$ & $1.40 \pm 0.02$ & 0.971 & $1.32 \pm 0.02$ & $1.40 \pm 0.02$ & 0.001 \\
\hline C20:0 & $0.23 \pm 0.07$ & $0.13 \pm 0.03$ & 0.001 & $0.27 \pm 0.01$ & $0.14 \pm 0.01$ & $<0.001$ \\
\hline C20:1 & $0.18 \pm 0.01$ & $0.15 \pm 0.01$ & 0.004 & $0.14 \pm 0.01$ & $0.12 \pm 0.01$ & 0.018 \\
\hline C20:3n 6 & $0.09 \pm 0.01$ & $0.08 \pm 0.09$ & 0.009 & $0.09 \pm 0.01$ & $0.09 \pm 0.01$ & 0.216 \\
\hline C20:4n6 & $0.10 \pm 0.01$ & $0.10 \pm 0.01$ & 0.189 & $0.08 \pm 0.04$ & $0.08 \pm 0.02$ & 0.072 \\
\hline $\mathrm{C} 20: 3 \mathrm{n} 3+\mathrm{C} 21: 0$ & $0.15 \pm 0.01$ & $0.05 \pm 0.03$ & $<0.001$ & $0.10 \pm 0.07$ & $0.04 \pm 0.04$ & $<0.001$ \\
\hline C20:5n 3 & $0.10 \pm 0.02$ & $0.06 \pm 0.01$ & $<0.001$ & $0.09 \pm 0.01$ & $0.08 \pm 0.06$ & 0.001 \\
\hline C22:0 & $1.04 \pm 0.03$ & $0.22 \pm 0.02$ & $<0.001$ & $1.00 \pm 0.08$ & $0.23 \pm 0.01$ & $<0.001$ \\
\hline SFA & $69.15 \pm 0.53$ & $71.99 \pm 0.44$ & 0.001 & $69.99 \pm 0.67$ & $71.88 \pm 0.24$ & 0.003 \\
\hline MUFA & $23.99 \pm 0.26$ & $24.18 \pm 0.44$ & 0.409 & $22.84 \pm 0.51$ & $24.37 \pm 0.17$ & 0.002 \\
\hline PUFA & $6.86 \pm 0.27$ & $3.83 \pm 0.03$ & $<0.001$ & $7.18 \pm 0.15$ & $3.75 \pm 0.07$ & $<0.001$ \\
\hline
\end{tabular}

The results are presented as mean \pm SD. Butyric acid (C4:0); caproic acid (C6:0); caprylic acid (C8:0); capric acid (C10:0); undecylic acid (C11:0); lauric acid (C12:0); tridecylic acid (C13:0); myristic acid (C14:0); myristoleic acid (C14:1); pentadecanoic acid (C15:0); palmitic acid (C16:0); palmitoleic acid (C16:1); stearic acid (C18:0); oleic acid (C18:1n9c); linoleic acid (C18:2n6); $\alpha$-linolenic acid (C18:3n3); arachidic acid (C20:0); cis11-eicosenoic acid (C20:1); homo- $\gamma$-linolenic acid (C20:3n6); arachidonic acid (C20:4n6); cis-11, 14, 17 eicosatrienoic acid + heneicosanoic acid (C20:3n3 + C21:0); eicosapentaenoic acid (EPA) (C20:5n3); behenic acid (C22:0); SFA - saturated fatty acids; MUFA - monounsaturated fatty acids; PUFA - polyunsaturated fatty acids. In each row and within each storage time a Student's $t$-test was performed to determine the significant between two different samples, with $\alpha=0.05: p>0.001$ means a significant difference between the samples.

Table 6 Antioxidant activity of the yogurts (expressed in $\mathrm{EC}_{50}$ values, $\mathrm{mg} \mathrm{mL}^{-1}$ ) throughout the shelf life

\begin{tabular}{llll}
\hline $\begin{array}{l}\text { Storage } \\
\text { time }\end{array}$ & Sample & $\begin{array}{l}\text { Reducing } \\
\text { power }\end{array}$ & $\begin{array}{l}\text { DPPH scavenging } \\
\text { activity }\end{array}$ \\
\hline 0 days & Control & $19.62 \pm 0.94$ & $>150$ \\
& Fortified & $5.53 \pm 0.09$ & $67.42 \pm 0.35$ \\
& $p$-Student's $t$-test & $<0.001$ & $<0.001$ \\
7 days & Control & $31.94 \pm 1.46$ & $>150$ \\
& Fortified & $4.59 \pm 0.14$ & $59.12 \pm 1.50$ \\
& $p$-Student's $t$-test & $<0.001$ & $<0.001$
\end{tabular}

The results are presented as mean $\pm \mathrm{SD}$. $\mathrm{EC}_{50}$ values correspond to the sample concentration achieving $50 \%$ of antioxidant activity or 0.5 of absorbance in reducing power assay. In each column and within each storage time a Student's $t$-test was performed to determine the significant difference between two different samples, with $\alpha=0.05: p>$ 0.001 means a significant difference between the samples.

dant one was palmitic acid (C16:0), followed by oleic acid (C18:1n9), myristic acid (C14:0) and stearic acid (C18:0). Heleno et al. $(2017)^{22}$ found a similar FA profile when analyzing dairy beverages added with $A$. bisporus extracts obtained by
UAE and ergosterol. The incorporation of the A. blazei rich extract in ergosterol promoted a significant alteration in our yogurt samples in terms of butyric acid (C4:0) and linoleic acid (C18:2n6). However, in general, the addition of the A. blazei extract did not significantly affect the FA profile of the samples, which stayed practically constant during the storage time.

The results of the reducing power and DPPH radical scavenging activity of the yogurts throughout seven days of the shelf life are given in Table 6. The incorporation of the A. blazei extract rich in ergosterol promoted statistically significant increases in the antioxidant capacity of the fortified yogurts, which was verified by both antioxidant assays $\left(\mathrm{EC}_{50}=4.59 \pm\right.$ $0.14 \mathrm{mg} \mathrm{mL}^{-1}$ in the reducing power assay and $\mathrm{EC}_{50}=59.12 \pm$ $1.50 \mathrm{mg} \mathrm{mL}^{-1}$ in the DPPH assay). Heleno et al. (2017) ${ }^{22}$ found a lower value of antioxidant capacity $\left(\mathrm{EC}_{50}=93 \mathrm{mg} \mathrm{mL} \mathrm{mL}^{-1}\right)$ when performing the DPPH assay for a yogurt incorporated with an A. bisporus mycosterol extract. Besides this, the antioxidant capacity of our fortified sample increased along the storage period (almost $17 \%$ in the reducing power assay and $12 \%$ in the DPPH assay), while there was a loss of antioxidant 
activity in the control sample verified by the reducing power assay. Such positive results confirm the antioxidant capacity of the studied A. blazei extract.

\section{Conclusion}

Commercially discarded $A$. blazei fruiting bodies, a Brazilian edible mushroom appreciated and produced worldwide, were studied for the obtainment of a rich extract in ergosterol via optimized Soxhlet extraction. The obtained results confirmed the viability of applying this A. blazei extract as a natural food fortifier, as it possesses not only notable antioxidant and antimicrobial properties besides showing no hepatotoxicity, but also enhances the antioxidant activity of yogurts. Convenient for food applications, the A. blazei extract did not significantly alter neither the nutritional composition nor the fatty acid profile of the assessed dairy products, despite the fact that it promoted a color alteration, which could also be explored by the food industry. Therefore, A. blazei fruiting bodies out of the commercial standard (bio-residues) could be used for obtaining a promising high added-value food additive, following the circular bioeconomy concept.

\section{Conflicts of interest}

There are no conflicts to declare.

\section{Acknowledgements}

R. C. G. Correa thanks the CAPES Foundation, Ministry of Education, Brazil (CAPES fellow, process number 88881.120010/2016-01), for the financial support provided for her postdoctoral research in the Polytechnic Institute of Bragança. The authors are grateful to the Foundation for Science and Technology (FCT, Portugal) and the FEDER under Programme PT2020 for financial support to CIMO (UID/AGR/ 00690/2013), L. Barros contract and A. Fernandes grant (SFRH/ BPD/114753/2016). This work was also funded by the European Structural and Investment Funds (FEEI) through the Regional Operational Program North 2020, within the scope of Project Mobilizador ValorNatural®. Rosane Marina Peralta and Adelar Bracht are recipients of scientific productivity research grants from CNPq (Conselho Nacional de Desenvolvimento Científico e Tecnológico, Brazil), grants numbers 307944/20158 and 304090/2016-6, respectively. M. Sokovic is grateful for financial support to the Ministry of Education, Science and Technological Development of Republic of Serbia, Grant No. 173032 .

\section{References}

1 R. C. Corrêa, R. M. Peralta, A. Bracht and I. C. F. R. Ferreira, The emerging use of mycosterols in food indus- try along with the current trend of extended use of bioactive phytosterols, Trends Food Sci. Technol., 2017, 67, 1935.

2 A. Gil-Ramírez, A. Ruiz-Rodríguez, F. R. Marín, G. Reglero and C. Soler-Rivas, Effect of ergosterol-enriched extracts obtained from Agaricus bisporus on cholesterol absorption using an in vitro digestion model, J. Funct. Foods, 2014, 11, 589-597.

3 M. Y. Yeh, W. C. Ko and L. Y. Lin, Hypolipidemic and Antioxidant Activity of Enoki Mushrooms (Flammulina velutipes), BioMed. Res. Int., 2014, 352385.

4 S. Y. Chen, K. J. Ho, Y. J. Hsieh, L. T. Wang and J. L. Mau, Contents of lovastatin, $\gamma$-aminobutyric acid and ergothioneine in mushroom fruiting bodies and mycelia, LWT-Food Sci. Technol., 2012, 47, 274-278.

5 V. Caz, A. Gil-Ramírez, M. Santamaría, M. Tabernero, C. Soler-Rivas, R. Martín-Hernandez, F. R. Marín, G. Reglero and C. Largo, Plasma Cholesterol-Lowering activity of lard functionalized with mushroom extracts is independent of Niemann-Pick C1-like 1 Protein and ABC sterol transporter gene expression in hypercholesterolemic mice, J. Agric. Food Chem., 2016, 64, 1686-1694.

6 J. H. Kang, J. E. Jang, S. K. Mishra, H. J. Lee, C. W. Nho, D. Shin, M. Jin, M. K. Kim, C. Choi and S. H. Oh, Ergosterol peroxide from Chaga mushroom (Inonotus obliquus) exhibits anti-cancer activity by down-regulation of the $\beta$-catenin pathway in colorectal cancer, J. Ethnopharmacol., 2015, 173, 303-312.

7 R. Nowak, M. Drozd, E. Mendyk, M. Lemieszek, O. Krakowiak, W. Kisiel, W. Rzeski and K. Szewczyk, A New Method for the Isolation of Ergosterol and Peroxyergosterol as Active Compounds of Hygrophoropsis aurantiaca and in Vitro Antiproliferative Activity of Isolated Ergosterol Peroxide, Molecules, 2016, 21, 946.

8 S. Torres, D. Cajas, G. Palfner, A. Astuya, A. Aballay, C. Pérez, V. Hernández and J. Becerra, Steroidal composition and cytotoxic activity from fruiting body of Cortinarius xiphidipus, Nat. Prod. Res., 2017, 31, 473-476.

9 T. Kikuchi, Y. Masumoto, Y. In, K. Tomoo, T. Yamada and R. Tanaka, Eringiacetal A, 5,6-seco-(5S,6R,7R,9S)5,6:5,7:6,9-Triepoxyergosta-8(14),22-diene-3 $\beta, 7 \beta$-diol, an Unusual Ergostane Sterol from the Fruiting Bodies of Pleurotus eryngii, Eur. J. Org. Chem., 2015, 4645-4649.

10 W. Li, W. Zhou, J. Y. Cha, S. U. Kwon, K. H. Baek, S. H. Shim, Y. M. Lee and Y. H. Kim, Sterols from Hericium erinaceum and their inhibition of TNF- $\alpha$ and NO production in lipopolysaccharide-induced RAW 264.7 cells, Phytochemistry, 2015, 115, 231-238.

11 I. P. Menikpurage, D. T. U. Abeytunga, N. E. Jacobsen and R. L. C. Wijesundara, An Oxidized Ergosterol from Pleurotus cystidiosus Active Against Anthracnose Causing Colletotrichum gloeosporioides, Mycopathologia, 2009, 167, 155-162.

12 V. J. Sinanoglou, P. Zoumpoulakis, G. Heropoulos, C. Proestos, A. Ćirić, J. Petrovic, J. Glamoclija and M. Sokovic, Lipid and fatty acid profile of the edible fungus 
Laetiporus sulphurous. Antifungal and antibacterial properties, J. Food Sci. Technol., 2015, 52, 3264-3272.

13 M. J. Feeney, A. M. Miller and P. Roupas, MushroomsBiologically Distinct and Nutritionally Unique: Exploring a “Third Food Kingdom”, Nutr. Today, 2014, 49, 301-307.

14 D. Stojković, F. S. Reis, J. Glamočlija, A. Ćirić, L. Barros, L. J. L. D. Van Griensven, I. C. F. R. Ferreira and M. Soković, Cultivated strains of Agaricus bisporus and A. brasiliensis: chemical characterization and evaluation of antioxidant and antimicrobial properties for the final healthy product - natural preservatives in yoghurt, Food Funct., 2014, 5, 1602-1612.

15 A. C. S. de Souza, V. G. Correa, G. A. Goncalves, A. A. Soares, A. Bracht and R. M. Peralta, Agaricus blazei Bioactive Compounds and their Effects on Human Health: Benefits and Controversies, Curr. Pharm. Des., 2017, 23, 2807-2834.

16 T. Shimizu, J. Kawai, K. Ouchi, H. Kikuchi, Y. Osima and R. Hidemi, Agarol, an ergosterol derivative from Agaricus blazei, induces caspase-independent apoptosis in human cancer cells, Int. J. Oncol., 2016, 48, 1670-1678.

17 H. Gao and W.-Y. Gu, Optimization of polysaccharide and ergosterol production from Agaricus brasiliensis by fermentation process, Biochem. Eng. J., 2007, 3, 202-210.

18 C. H. Shu and K. J. Lin, Effects of aeration rate on the production of ergosterol and blazeispirol A by Agaricus blazei in batch cultures, J. Taiwan Inst. Chem. Eng., 2011, 42, 212216.

19 M. Carocho and I. C. F. R. Ferreira, A review on antioxidants, prooxidants and related controversy: natural and synthetic compounds, screening and analysis methodologies and future perspectives, Food Chem. Toxicol., 2013, 51, 15-25.

20 C. Caleja, L. Barros, A. L. Antonio, M. Carocho, M. B. P. Oliveira and I. C. Ferreira, Fortification of yogurts with different antioxidant preservatives: A comparative study between natural and synthetic additives, Food Chem., 2016, 210, 262-268.

21 C. Caleja, L. Barros, A. L. Antonio, A. Ciric, M. Soković, M. B. P. P. Oliveira, C. Santos-Buelga and I. C. F. R. Ferreira, Foeniculum vulgare Mill. as natural conservation enhancer and health promoter by incorporation in cottage cheese, J. Funct. Foods, 2015, 12, 428-438.

22 S. A. Heleno, A. R. Rudke, R. C. Calhelha, M. Carocho, L. Barros, O. H. Gonçalves, M. F. Barreiro and I. C. F. R. Ferreira, Development of dairy beverages functionalized with pure ergosterol and mycosterol extracts an alternative to phytosterol-based beverages, Food Funct., 2017, 8, 103110.

23 CLSI, Approved standard, $8^{\text {th }}$ ed. CLSI publication M07-A8, Clinical and Laboratory Standards Institute, Wayne, PA, 2009.

24 D. S. Stojković, N. Kovačević-Grujičić, F. S. Reis, S. Davidović, L. Barros, J. Popović, I. Petrović, A. Pavić, J. Glamočlija, A. Ćirić, M. Stevanović, I. C. F. R. Ferreira and M. Soković, Chemical composition of the mushroom
Meripilus giganteus Karst. and bioactive properties of its methanolic extract, LWT-Food Sci. Technol., 2017, 79, 454462.

25 R. M. V. Abreu, I. C. F. R. Ferreira, R. C. Calhelha, R. T. Lima, M. H. Vasconcelos, F. Adega, R. Chaves and M. J. R. P. Queiroz, Anti-hepatocellular carcinoma activity using human HepG2 cells and hepatotoxicity of 6-substituted methyl 3-aminothieno[3,2-b]pyridine-2-carboxylate derivatives: In vitro evaluation, cell cycle analysis and QSAR studies, Eur. J. Med. Chem., 2011, 46, 5800-5806.

26 AOAC International and W. George Jr., AOAC, Association of Official Analytical Chemists, Rockville, MD, USA, 20th edn, 2016.

27 J. Azmir, I. S. M. Zaidul, M. M. Rahman, K. M. Sharif, A. Mohamed, F. Sahena, M. H. A. Jahurul, K. Ghafoor, N. A. N. Norulaini and A. K. M. Omar, Techniques for extraction of bioactive compounds from plant materials: a review, J. Food Eng., 2013, 117, 426-436.

28 S. A. Heleno, P. Diz, M. A. Prieto, L. Barros, A. Rodrigues, M. F. Barreiro and I. C. F. R. Ferreira, Optimization of ultrasound-assisted extraction to obtain mycosterols from Agaricus bisporus L. by response surface methodology and comparison with conventional Soxhlet extraction, Food Chem., 2016, 197, 1054-1063.

29 A. Gil-Ramírez, L. Aldars-García, M. Palanisamy, R. M. Jiverdeanu, A. Ruiz-Rodríguez, F. R. Marín, G. Reglero and C. Soler-Rivas, Sterol enriched fractions obtained from Agaricus bisporus fruiting bodies and byproducts by compressed fluid technologies (PLE and SFE), Innovative Food Sci. Emerging Technol., 2013, 18, 101-107.

30 J. C. M. Barreira, M. B. P. P. Oliveira and I. C. F. R. Ferreira, Development of a novel methodology for the analysis of ergosterol in mushrooms, Food Anal. Methods, 2014, 7, 217-223.

31 S. A. Heleno, M. A. Prieto, L. Barros, A. Rodrigues, M. F. Barreiro and I. C. F. R. Ferreira, Optimization of microwave-assisted extraction of ergosterol from Agaricus bisporus L. by-products using response surface methodology, Food Bioprod. Process, 2016, 100, 25-35.

32 S. Mazzutti, S. R. Ferreira, C. A. Riehl, A. Smania, F. A. Smania and J. Martínez, Supercritical fluid extraction of Agaricus brasiliensis: Antioxidant and antimicrobial activities, J. Supercrit. Fluids, 2012, 70, 48-56.

33 S. Jia, F. Li, Y. Liu, H. Ren, G. Gong, Y. Wang and S. Wu, Effects of extraction methods on the antioxidant activities of polysaccharides from Agaricus blazei Murrill, Int. J. Biol. Macromol., 2013, 62, 66-69.

34 F. Mourão, S. H. Umeo, O. S. Takemura, G. A. Linde and N. B. Colauto, Antioxidant activity of Agaricus brasiliensis basidiocarps on different maturation phases, Braz. J. Microbiol., 2011, 42, 197-202.

35 A. A. J. Carneiro, I. C. F. R. Ferreira, M. Dueñas, L. Barros, R. da Silva, E. Gomes and C. Santos-Buelga, Chemical composition and antioxidant activity of dried powder formulations of Agaricus blazei and Lentinus edodes, Food Chem., 2013, 138, 2168-2173. 
36 R. C. G. Corrêa, C. W. I. Haminiuk, L. Barros, M. I. Dias, R. C. Calhelha, C. G. Kato, V. G. Correa, R. M. Peralta and I. C. F. R. Ferreira, Stability and biological activity of Merlot (Vitis vinifera) grape pomace phytochemicals after simulated in vitro gastrointestinal digestion and colonic fermentation, J. Funct. Foods, 2017, 36, 410-417.
37 A. C. P. Vital, P. A. Goto, L. N. Hanai, S. M. G. da Costa, B. A. A. Filho, C. V. Nakamura and P. T. Matumoto-Pintro, Microbiological, functional and rheological properties of low fat yogurt supplemented with Pleurotus ostreatus aqueous extract, LWT-Food Sci. Technol., 2015, 64, 10281035. 